\title{
Gram per Mole
}

National Cancer Institute

\section{Source}

National Cancer Institute. Gram per Mole. NCI Thesaurus. Code C73721.

A unit of mass commonly used to express the molar mass of a substance in gram(s) per mole. 